\title{
抗精神病薬投与患者に対する全身麻醉下での手術経験
}

山田庸介・木村卓爾·三崎昌和

岸本晃治・寺門永顕・松村智弘

\section{Surgical experience with general anesthesia in patients receiving long-term antipsychotic drug therapy}

\author{
Yousuke Yamada - Takuji Kimura $\cdot$ Masakazu Misaki \\ Koji Kishimoto $\cdot$ Nagaaki Terakado $\cdot$ Tomohiro Matsumura
}

\begin{abstract}
Recently, some patients, receiving long-term antipsychotic therapy, particularly with phenothiazines, have been reported to die suddenly and unexpectedly. These patients may have underlying diseases of organs such as the liver, heart and endocrine glands. General anesthesia and surgery can be difficult in these patients. Therefore, care should be taken with regard to drug therapy (dosage and treatment period), laboratory findings, and general condition.
\end{abstract}

Key words: antipsychotic drug (抗精神病薬), phenothiazines (フェノチアジン), endocrine (内 分泌の)

\section{緒言}

抗精神病薬は，一般に長期間継続投与されているこ とが多く，さまざまな副作用や手術の際に合併症が出 現することが知られている(表 1$\left.)^{1}\right)^{1}$ 。このため手術 にあたり，患者の全身状態を評価し，可及的にストレ スを軽隇しうる手術法, 麻酔法を選択して合併症の防 止につとめるとともに詳細な術中, 術後管理を行うこ とが重要である．今回われわれは，抗精神病薬服用患 者 3 名の全身麻酔下の手術を経験し，若干の知見を得 たので文献的考察を加え，その概要を報告する.

\section{症 例 1}

患 者: 51 歳, 男性

主 訴: 発音障害

現病歴 : 30 歳頃, 下顎舌側腫瘤を認めるが症状がな いため放置, その後, 嚥下, 発音障害が出現し, 昭和 63 年 8 月—当科紹介受診した。

既往歴: 21 歳頃より精神分裂病発病, 塩酸クロカプ

岡山大学菌学部口腔外科学第二講座

(主任 : 松村智弘教授)

Department of Oral and Maxillofacial Surgery II, Okayama University Dental School (Chief: Prof.

Tomohiro Matsumura)

受付日: 平成 6 年 11 月 21 日
表 1 抗精神薬の副作用および合併症

\begin{tabular}{l|l}
\hline 1. 精神症状 & 傾眠, 抑うつ, 精神運動性症状 \\
2. 自律神経異常 & 低血圧, 口渇, 頻脈, 虚脱 \\
3. 循環器系異常 & 心電図異常, 肺栓塞, ショック \\
4. 肝機能異常 & 黄疸, 腹水 \\
5. 血液系の異常 & 顆粒球隇少症 \\
6. 消化器系の異常 & 胃潰瘍, 麻痷性イレゥス, 急性胃拡張 \\
7. 内分泌系の異常 & 副腎皮質機能低下, 肥満 \\
8. その他 & Syndrome malin, 突然死 \\
& Drug interactionの増強 \\
\hline
\end{tabular}

ラミン（50mg／日）を 30 年間服用中であった.

術前検査：PSP 試験で低值を認めた（表 2 ）.

臨床診断：下顎骨骨腫

抗精神病薬の投薬スケジュールと全身麻酔経過 : 精 神状態が安定しており，塩酸クロカプラミンは手術 14 日前より休薬した. 全身麻酔はジアゼパム $15 \mathrm{mg}$ 静注 後，意識下気管内挿管を行い，維持は笑気，酸素，工 ンフルレンを用いた．急激な血中濃度増加に伴う副作 用を防ぐため，塩酸クロカプラミンは，手術翌日より 半量 $25 \mathrm{mg}$ 開始し, 術後 15 日目より $50 \mathrm{mg}$ に増量し た. 術中, 術後問題なく, 術後 45 日目退院となった. 


\section{症 例 2}

患 者 : 53 歳, 女性

主 訴: 右下顎部腫脹

現病歴 : 平成 4 年 5 月頃より右下顎臼歯部腫脹を認 め, 入院中の病院より平成 4 年 6 月—当科紹介受診 した。

既往歴：40歳頃より精神分裂病発病. ハロペリドー ル，レボメプロマジンを約 10 年間服用していたが精 神状態の安定に伴い，半年前より中止していた。

術前検査：血漿アルドステロンがやや低值を示し， 副腎皮質機能低下が疑われた（表 2 ）.

臨床診断：右側下顎臼歯部歯根囊胞

全身麻酔経過：NLA 変法 (ジアゼパム, ブトルファ ノール）で導入し，笑気，酸素，およびセボフルレン で維持した，術前検査より副腎皮質機能低下を疑い， ステロイドカバーとしてヒドロコルチゾン $100 \mathrm{mg}$ 投 与. 術後 7 時間後, ヒドロコルチゾン $100 \mathrm{mg}$ 追加投与. 術中, 術後問題なく術後 17 日目退院となった.

\section{症 例 3}

患 者: 30 歳, 男性

主 訴：右下顎部咬合痛

現病歴：平成 4 年 4 月某歯科にて, 右第一大 臼歯根尖部の X 線透過像を指摘され, 当科紹介受診 した。

既往歴 : 20 歳頃より精神分裂病発病し, 塩酸クロカ プラミン（75mg/日), ピモジド（ $9 \mathrm{mg} /$ 日)，プロ ムペリドール（18mg／日）を約 8 年間服用中であっ た.

術前検查：ECG 上 QT 間隔延長，多尿（5000$7000 \mathrm{ml} / \mathrm{day}), \mathrm{PSP}$ 試験の軽度低值，および ICG 試 験の軽度高値を示した。尿中 17-OHCS, 17-KS が軽度 低値を示し副腎皮質機能低下が疑われた（表 2 ）。

臨床診断：右側下顎臼歯部歯根囊胞

抗精神病薬投薬のスケジュールと全身麻酔経過 : 全 身麻酔は, 幻覚妄想状態の残存のため, 手術日のみ休 薬した. 全身麻酔は, NLA 変法 (ジアゼパム, フェン タニール）で導入し，笑気，酸素，およびフェンタニー ルで維持した。術前検査より副腎皮質機能低下が疑い, ステロイドカバーとしてヒドロコルチゾン 100mg を 2 回投与した. 術後, ECG 上 $\mathrm{QT}$ 間隔延長と多尿を認 めた他は問題なく, 術後 16 日目退院となった。

\section{考察}

抗精神病薬を長期投与すると中枢神経系, 循環系, 肝, 腎, 血液, 内分泌系, および消化器系などに影響 を与え, 種々の副作用を発生させることは以前から指 摘されてきた ${ }^{2}$ ). そのため抗精神病薬長期服用患者 は外見上, 健康であっても諸臓器は, 機能が抑制され ていると言われている3 ${ }^{3}$ ．手術に際し問題とされる
表 2 術前検査所見

\begin{tabular}{|c|c|c|c|}
\hline & 症例 1 & 症例 2 & 症例 3 \\
\hline \multicolumn{4}{|l|}{ 一般血液検査 } \\
\hline WBC $\left(/ \mathrm{mm}^{3}\right)$ & 4800 & 3400 & 4200 \\
\hline $\mathrm{RBC}\left(/ \mathrm{mm}^{3}\right)$ & $359 \times 10^{4}$ & $473 \times 10^{4}$ & $482 \times 10^{4}$ \\
\hline $\mathrm{Hgb}(\mathrm{g} / \mathrm{dl})$ & 10.5 & 12.3 & 14.7 \\
\hline Het $(\%)$ & 32.2 & 41.5 & 43.6 \\
\hline $\begin{array}{l}\mathrm{PLT}\left(/ \mathrm{mm}^{3}\right) \\
\text { 血液生化学検査 }\end{array}$ & $174 \times 10^{3}$ & $273 \times 10^{3}$ & $195 \times 10^{3}$ \\
\hline $\mathrm{TP}(\mathrm{g} / \mathrm{l})$ & 7.55 & 7.29 & 7.17 \\
\hline Alb $(\mathrm{g} / \mathrm{dl})$ & 4.22 & 4.35 & 4.84 \\
\hline GOT (IU $/ 1)$ & 18 & 25 & 10 \\
\hline GPT (IU $/ 1)$ & 8 & 26 & 9 \\
\hline$\gamma-\mathrm{GTP}(\mathrm{IU} / \mathrm{l})$ & 13 & 23 & 18 \\
\hline $\mathrm{Na}(\mathrm{mmol} / \mathrm{l})$ & 137 & 137 & 141 \\
\hline $\mathrm{K}(\mathrm{mmol} / \mathrm{l})$ & 4.3 & 3.6 & 3.6 \\
\hline $\mathrm{Cl}(\mathrm{mmol} / \mathrm{l})$ & 101 & 101 & 105 \\
\hline $\mathrm{Ca}(\mathrm{mg} / \mathrm{dl})$ & 8.7 & 8.5 & 8.8 \\
\hline BUN（mg / dl) & 18.5 & 6.6 & 5.5 \\
\hline CRTN $(\mathrm{mg} / \mathrm{dl})$ & 1.09 & 0.48 & 0.90 \\
\hline $\begin{array}{l}\text { 心電図所見 } \\
\text { PSP 検査（\%） }\end{array}$ & W.N.L. & W.N.L. & QT 延長 \\
\hline 15 分値 & 2.1 & 42.1 & 19.5 \\
\hline 30 分值 & 6.2 & 56.5 & 36.2 \\
\hline 90 分値 & 20.3 & 74.2 & 49.0 \\
\hline $\begin{array}{l}120 \text { 分値 } \\
\text { ICG 検査 }(\%)\end{array}$ & 35.9 & 81.9 & 58.9 \\
\hline $\begin{array}{l}15 \text { 分値 } \\
\text { 内分泌機能検査 }\end{array}$ & & 10.9 & 12.5 \\
\hline $\mathrm{ACTH}(\mathrm{pg} / \mathrm{ml}$ )（基準值 ; & $4.4-48.0)$ & 16.0 & 25.0 \\
\hline Cortizol $(\gamma \mathrm{g} / \mathrm{dl})$ （基準值 & ; 3.1-15.2) & 48.8 & 87.6 \\
\hline $\begin{aligned} \text { Aldosteron } & (3 \mathrm{pg} / \mathrm{ml}) \\
& \text { (基準値 ; } 56.9-\end{aligned}$ & $150.3)$ & 4.7 & 1.6 \\
\hline $\begin{array}{l}17-\text { OHCS }(\mathrm{mg} / \text { day }) \\
\text { （基準値 ; } 2.1-11 .\end{array}$ & & & 0.6 \\
\hline 17-KS（mg／day）（基準値 & ; 3.5-13.0) & & 1.05 \\
\hline
\end{tabular}

のは, 術後の突然死であり, 抗精神病薬, とくに, フェ ノチアジン系薬剂長期服用により循環系への影響とし て突然起きる激しい低血圧，著明な心機能障害，およ び心機能停止が論じられている ${ }^{4)}$. フェノチアジン服 用時の低血圧は末梢性血管拡張作用，血管収縮作用の 抑制作用によると考えられており，多くは起立性低血 圧で，重篤な副作用とはならないが，持続性ショック 状態から何らかの誘因で虚脱状態を引き起こす可能性 もある ${ }^{5}$ ）。このため，手術の際は，全身状態，抗精神 病薬服用歴 (種類, 投与量, 投与期間) 等を術前にチェッ クし, 副腎皮質機能低下が疑われる際は，ステロイド カバーも必要となる。また, 術前から術後にかけての 休薬が一般的に行われるが, 薬物の急激な休薬は, 循 環器系や自立神経系のホメオスターシスに不安定をも たらす可能性もあるため，準備期間があれば，患者の 精神状態を考慮しながら漸減することが望ましいと松 
表 3 術前術後の血圧, 手術時間, 麻酔時間, 出血量, 術 中の血圧の変動

\section{症例 1}

術前術後の血圧: 術前の血圧は, $120 / 70 \mathrm{mmHg}$ 術後 の血圧は, $100 / 70 \mathrm{mmHg}$ で, 異常な かった.

手術時間 : 3 時間 30 分

麻酔時間 : 5 時間

出血量 : $250 \mathrm{ml}$

術中の血圧の変動：収縮期血圧 $100 \mathrm{mmHg}$, 拡張期血圧 $60 \mathrm{mmHg}$ 前後で安定していた.

症例 2

術前術後の血圧 : 術前の血圧は, $110 / 50 \mathrm{mmHg}$ で あったが, 術後血圧は $150 / 90 \mathrm{mmHg}$ 前後に上昇した。

手術時間：55 分

麻酔時間：2 時間 30 分

出血 $\mathrm{7}: 25 \mathrm{ml}$

術中の血圧の変功：収縮期血圧 $110 \mathrm{mmHg}$ ，拡張期血圧 $60 \mathrm{mmHg}$ 前後で安定していた

症例 3

術前術後の血圧 : 術前の血圧は, $120 / 70 \mathrm{mmHg}$ で異常 なかったが, 術後血圧は140/ $80 \mathrm{mmHg}$ 前後に上昇した

手術時間：1 時間 25 分

麻酔時間: 2 時間 5 分

出血量: $85 \mathrm{ml}$

術中の血圧の変功：収縮期血圧 $120 \sim 140 \mathrm{mmHg}$, 拡張期血圧 $70 \mathrm{mmHg}$ 前後で安定し ていた.

脈拍数は 60 回／分前後で安定して いた。

木ら ${ }^{6)}$ は述べている. 症例 1 の患者は精神状態も安 定していたため，手術 14 日前より休薬し，手術翌日 より半量再開, 15 日後より術前投与量に増量した。一 方, 症例 3 の患者は幻覚, 妄想状態が残存しており, 休薬によって病状覀化の可能性もあるため, 休薬は手 術日のみとした。術前検査は, 症例 $2 ， 3$ では内服薬 が副作用の強いとされるフェノチアジン系, ブチロフェ ノン系であり，副腎皮質機能検査も行い，いずれも副 腎皮質機能低下が疑われ，ステロイドカバーを行った. また，症例 3 で術前，術後に見られた多康は，口渴感 のために水分捸取量が多かったことによるもので，抗 精神病薬の抗コリン作用による唾液分泌抑制が示唆さ れた。手術の際，局所麻酔と全身麻酔との選択は，患 者の全身状態，精神状態，および手術侵襲を総合的に 判断した上で決定する必要がある，抗精神病薬と麻酔
表 4 抗精神薬と麻酔剂との Drug interaction

\begin{tabular}{|c|c|}
\hline 1.吸入麻酔剤 & $\begin{array}{l}\text { 覚醒遅延 } \\
\text { 最小肺胞内濃度 (MAC) 減少 }\end{array}$ \\
\hline 2.ハロセン & 不整脈，房室解離 \\
\hline 3. 麻薬 & 鎮痛効果, 呼吸抑制増強 \\
\hline 4.バルビタール剂 & 睡眠時間延長, 呼吸抑制増強 \\
\hline 5.パンクロニウム & 頻脈，血圧上昇 \\
\hline 6.スコポラミン & 中枢性抗コリン性症候群 \\
\hline 7.昇圧剤 & $\begin{array}{l}\text { 昇圧効果増強, 発汗, 発熱 } \\
\text { 頭痛, 不整脈 }\end{array}$ \\
\hline
\end{tabular}

関連薬との相互作用が論じられており (表 4$)^{7}$ ），術 前検査により薬剂の選択も考慮する必要がある。症例 1 では精神状態は安定しているが，手術侵襲を考え， 全身麻酔を選択した．症例 $2 ， 3$ では囊胞が X 線上， 下歯槽神経を含んでおり，局所麻酔ではかなりの疼痛 が予想され，術中に精神状態が悪化し，治療の協力が 得られなくなる恐れもあるため，全身麻酔を選択した。

\section{結語}

今回われわれは, 抗精神病薬長期服用患者の全身麻 酔下手術 3 例を経験したので，文献的考察を加え，そ の概要を報告した，手術にあたり，抗精神病薬の治療 歴についての十分な確認と術前, 術中, 術後における 配慮が必要であると考える。

謝辞

稿を終えるにあたり，ご教示いただいた岡山大学歯学部 付属病院歯科麻酔科，島田昌彦教授に深謝いたします。

\section{参 考 文 献}

1）木下 潤 : 抗精神病薬の使い方と随伴症状. 吉 富製薬，大阪，1979，29-75 頁.

2 ）村川徳昭, 若山茂春, 他: 精神分裂病患者の麻 酔および手術一向精神薬長期投与患者の諸問題一. 外科 40: 377-382 1978 .

3 ) 長坂五郎 : 向精神薬の副作用のチェックおよび 予防について. 精神医学 13: 469-475 1971.

4 ) 酒井正雄, 大西一徳, 他: 向精神薬の心臓, 血 管系に及ほす影響一phenothiazine 系薬物を 中心として一. 精神医学 13: 477-484 1971.

5 ) 渡辺昌祐 : 向精神薬, 抗てんかん薬の副作用. 現代精神医学大系 (5B) 内村祐之, 懸田克躬, 他 (編)，中山書店，東京，1977，280-282.

6 ) 三浦貞則: 精神分裂病, 抗精神病薬, 外科手術. 臨床麻酔 $9: 334-3361985$.

7 ) 松木美智子 : 精神分裂病患者の手術, 麻酔時の 投薬について．臨床麻酔 5 ：1228-1229 1981 . 